III. - GENETICS

\title{
Trends observed in the Rouille pig selection experiment (1965-1984)
}

\author{
L. OLLIVIER *, J. GRUAND**, C. FELGINES * \\ *I.N.R.A., Station de Génétique quantitative et appliquée, 78350 Jouy-en-Josas \\ ** Station de Sélection porcine, 86480 Rouille
}

\begin{abstract}
An account is given of a pig selection experiment begun in 1965 at the I.N.R.A. artificial insemination center of Rouillé (Vienne). Altogether, 19 successive Large White boar generations (1965-1983) have been compared on 5610 progeny tested from 1966 to 1984 . The boars were selected on a performance-test index including growth rate and backfat thickness. Selection responses were measured, using a « repeat sire » design, separately in the 2 periods 1965-1975 and 1975-1983, for growth, feed efficiency, body composition, meat quality and development of the nasal turbinates. The results showed an increase in annual genetic gains in the 2 nd period. These annual gains were 9 and $13 \mathrm{~g} /$ day in growth rate, -0.044 and -0.047 in feed conversion ratio, 0.3 and 0.7 in percentage lean tissue, in the 2 periods, respectively. Indirect responses in meat quality were of low magnitude and the tendency towards a paler meat colour in the 1st period was quite reduced in the 2 nd. However, the unfavourable trends observed in nasal turbinates development were significant in both periods. Those results are discussed in the light of the genetic parameters of the population and the selection applied to the boars. With regard to this point, the analysis shows an important discrepancy between the index used to rank the boars and the a posteriori index, which indicates that among the top ranking boars the leanest ones were preferentially discarded.
\end{abstract}

\section{Genetic trends for growth and carcass traits in Large White, French Landrace and Belgian Landrace pig breeds}

\author{
Michèle TIXIER, P. SELLIER \\ I.N.R.A., Station de Génétique quantitative et appliquée \\ 78350 Jouy-en-Josas
}

Annual genetic gains between 1970 and 1980 in Large White (LW), French Landrace (FL) and Belgian Landrace (BL) pig breeds were estimated for growth and carcass traits. Data collected in progeny-testing stations (P) and boar individual testing stations (I) were analysed both by the method of within-sire regression of performance on time (SMITH, 1962) and by means of a mixed linear model including the effects of year of birth of sire and dam. Estimates of genetic trends given below are those obtained by pooling the results of the two methods. 
Estimates of the annual genetic trends for average daily gain ( $\mathrm{g}$ ) and food conversion ratio ( $\mathrm{kg} \mathrm{feed} / \mathrm{kg}$ gain) in the $\mathrm{LW}$ breed $+2.9 \pm 0.8 \mathrm{~g}$ and $-0.011 \pm 0.002 \mathrm{~kg} / \mathrm{kg}$ were respectively in $\mathrm{I}$ stations, $-4.7 \pm 2.1 \mathrm{~g}$ and $-0.003 \pm 0.007 \mathrm{~kg} / \mathrm{kg}$ in $\mathrm{P}$ stations. The corresponding estimated for the FL breed were $+1.0 \pm 0.9 \mathrm{~g}$ and $-0.008 \pm 0.003 \mathrm{~kg} / \mathrm{kg}$ respectively in I stations, $+3.2 \pm 2.7 \mathrm{~g}$ and $-0.022 \pm 0.008 \mathrm{~kg} / \mathrm{kg}$ in $\mathrm{P}$ stations. For the $\mathrm{BL}$ breed, they were $-2.5 \pm 1.4 \mathrm{~g}$ and $+0.003 \pm 0.004 \mathrm{~kg} / \mathrm{kg}$ respectively in I stations, $-0.8 \pm 2.8 \mathrm{~g}$ and $-0.018 \pm 0.009 \mathrm{~kg} / \mathrm{kg}$ in $\mathrm{P}$ stations. Annual genetic trends in muscle content of the carcass (P stations) and average backfat thickness (I stations) were $+0.42 \pm$ 0.07 p. 100 and $-0.26 \pm 0.02 \mathrm{~mm}$ respectively for the $\mathrm{L} . \mathrm{W}$ breed, $+0.15 \pm 0.10 \mathrm{p} .100$ and $0.16 \pm 0.02 \mathrm{~mm}$ for the FL breed, $+0.33 \pm 0.09 \mathrm{p} .100$ and $-0.19 \pm 0.03 \mathrm{~mm}$ for the BL breed.

As compared to the expected responses from the boar selection index of I stations, estimated genetic gains were relatively greater for body composition than for growth traits.

\title{
Genetic relationships between station performance-testing and " on-farm " testing in pigs
}

\author{
P. SELLIER *, R. GUEBLEZ **, D. LALOE***, \\ J.P. RUNAVOT **, L. OLLIVIER * \\ *I.N.R.A., Station de Génétique quantitative et appliquée \\ 78350 Jouy-en-Josas \\ ** I.T.P., Région Ouest, B.P. 3, 35650 Le Rheu \\ *** U.P.R.A. Porcine, 95 bis, boulevard Pereire, 75017 Paris
}

Pig breeding for growth and carcass traits in France is based on performance recording both in central testing stations (S) and in breeding farms (F). Data collected in boar performance-test stations (1979-1983) and in the "on-farm » programme (1981-1983), on Large White and French Landrace pigs, were analysed in order to estimate genetic correlations between traits measured in the $S$ and $F$ environments. The $S$ traits are average daily gain $\left(\mathrm{ADG}_{\mathrm{s}}\right)$ and food conversion ratio (FCR $)$ from 35 to $90 \mathrm{~kg}$, and ultrasonic backfat thickness at $90 \mathrm{~kg}\left(B F T_{\mathrm{S}}\right)$. The $\mathrm{F}$ traits are age at $100 \mathrm{~kg}\left(\mathrm{AGE}_{\mathrm{r}}\right)$ and ultrasonic backfat thickness at $100 \mathrm{~kg}\left(\mathrm{BFT}_{\mathrm{F}}\right)$. Data sets used for estimating genetic variances included 25298 boars from 4656 sires for $S$ traits, and 96711 boars $(1 / 3)$ or gilts $(2 / 3)$ from 2292 sires for $F$ traits (104 herds). Genetic covariances between $S$ and $F$ traits were derived from sire-offspring covariance on one hand (18325 F offspring from $302 \mathrm{~S}$ sires), and from paternal half-sib covariances on the other hand (1117 sires with $55697 \mathrm{~F}$ offspring and $5743 \mathrm{~S}$ sons). The pooled estimates of genetic correlation $\left(r_{A}\right)$ between $S$ and $F$ traits are as follows : $-0.41 \pm$ 0.07 for $\mathrm{ADG}_{\mathrm{S}}$ and $\mathrm{AGE}_{\mathrm{F}},-0.10 \pm 0.05$ for $A \mathrm{ADG}_{\mathrm{S}}$ and $\mathrm{BFT}_{\mathrm{F}}, 0.39 \pm 0.05$ for $\mathrm{FCR}_{\mathrm{S}}$ and $\mathrm{AGE}_{\mathrm{F}}, 0.23 \pm 0.05$ for $\mathrm{FCR}_{\mathrm{S}}$ and $\mathrm{BFT}_{\mathrm{F}}, 0.05 \pm 0.05$ for $\mathrm{BFT}_{\mathrm{S}}$ and $\mathrm{AGE}_{\mathrm{F}}$, and $0.53 \pm 0.05$ for $\mathrm{BFT}_{\mathrm{S}}$ and $\mathrm{BFT}_{\mathrm{F}}$. Separate analyses by sex of "on-farm» pigs suggest a genotype $\mathrm{x}$ sex interaction for growth traits, the $\mathrm{r}_{\mathrm{A}}^{\prime} \mathrm{S}$ being higher for the boar-boar than for the boar-gilt relationship (-0.57 $\pm 0.09 v s-0.35 \pm 0.06$ for $\mathrm{ADG}_{\mathrm{s}}$ and $\mathrm{AGE}_{\mathrm{F}}$, and $0.61 \pm 0.09 v \mathrm{~s}$ $0.31 \pm 0.06$ for $\mathrm{FCR}_{\mathrm{s}}$ and $\mathrm{AGE}_{\mathrm{F}}$, respectively). The genotype $\mathrm{x}$ environment interaction effects explaining that the observed $r^{\prime}$ 'S between similar $S$ and $F$ traits deviate from the «expected » value of 1 (or - 1) are briefly discussed in relation to the feeding system, test period, sex and housing differences between the two breeding environments. 